\title{
Between Privileged and Oppressed? Immigrant Labor Trajectories in Norwegian Long-Term Care
}

\author{
Laila Tingvold ${ }^{1, *(\mathbb{D})}$ and Anette Fagertun ${ }^{2}$ \\ 1 Centre for Care Research East, Norwegian University of Science and Technology, 2215 Gjøvik, Norway \\ 2 Centre for Care Research West, Western Norway University of Applied Sciences (HVL), \\ 5020 Bergen, Norway; Anette.Fagertun@hvl.no \\ * Correspondence: Laila.tingvold@ntnu.no; Tel.: +47-98245147
}

Received: 18 April 2020; Accepted: 2 June 2020; Published: 11 June 2020

\begin{abstract}
An increase in older people coupled with growing life expectancy has created a higher demand for long-term care (LTC) services in the global North. Recruitment of staff with an immigrant background has been a solution to meet this demographic challenge. Research shows that linguistic barriers and cultural differences can influence immigrant carers' abilities to offer adequate care, while less is known about workplace training and intra-collegial support. This article explores systems and practices of training offered to new employees with immigrant backgrounds, and how the qualification process unfolds in daily work in nursing homes in Norway through an intersectional perspective focusing on the interlocking of gender, class and migrancy. The article shows that organizational conditions together with incomplete training combined with attitudes of 'willful ignorance' maintain privilege and oppression in these workplaces. The increased immigrant participation and their labor trajectories indicate the emergence of a new immigrant niche in the lower tiers of the LTC sector. The article contributes to the literature of migration, gender, healthcare services and labor by exploring immigrants' situated labor experiences within changing institutional conditions in LTC.
\end{abstract}

Keywords: immigrant workers; multicultural staff; long-term care; flexibilization; immigrant niche; intersectionality

\section{Introduction}

A considerable increase in the number of elderly people coupled with growing life expectancy has resulted in increased demand for long-term care (LTC) services in Norway and the global North. Improved treatment outcomes, access to new medication as well as treating more health problems are additional factors that increase the number of users and the demand for health and care services $[1,2]$.

In the context of Norway, some municipalities already experience problems recruiting healthcare personnel, and a few have taken action in order to make nursing homes more attractive as workplaces by, for example, offering full-time positions with favorable shift solutions [3]. Recruitment of staff with an immigrant background has also been proposed as a solution to the coming demographic challenges [4,5].

So far, supported employment such as 'place then train' efforts and recruiting low-skilled staff to become auxiliary nurses, has been insufficient to meet the increased demand for care workers [6-8]. However, the gap between the supply and demand of LTC workers would have been even more critical without the recruitment and increase of immigrant workers, especially within the long-term care sector [6]. A growing number of immigrants have also received training at the workplace via NAV (Norwegian Labor and Welfare Administration). NAV administers a third of the national budget through schemes such as unemployment benefits, work assessment allowances, sickness benefits, 
pensions, child benefits and cash-for-care benefits. Immigrants may also receive training through other initiatives in line with the ideology of 'place then train' (training within regular work life) as a new way of including marginalized groups in the labor market $[7,8]$.

In recent years, immigrants have carried out an increasing amount of FTEs (full-time equivalents) in the long-term care sector in Norway. In 2009, immigrants carried out 11 per cent of FTEs, while by 2017, this had increased to 17 per cent of the total 142,000 person-years in the long-term care services [9]. Immigrants are understood as: "persons born abroad of two foreign-born parents and four foreign-born grandparents" [9]. People from Asia constitute a large group of employees in Norwegian LTC and they accounted for one-third of the contractual immigrant person-years in 2017. There has also been an increase in the number of employees from countries in Africa [9] and Eastern Europe [10]. About $25 \%$ of the total workforce in LTC are low-skilled, defined as workers without formal education, and approximately $50 \%$ of the immigrant workers are in this category [11]. Immigrant workers have less absence due to illness and include a higher percentage of men than the majority workers where women account for about $85 \%$ of care staff $[10,12]$. Some of the low-skilled staff have, however, gained considerable practical experience over the years and have obtained high caring competence as care workers [13-15]. When using 'low skills' in the continuation of this article, we refer to staff without formal care education, and to positions that require lower skills than, for example, registered or auxiliary nurses in LTC.

In the long-term care sector, the wages are relatively low, shifts are characterized by heavy workloads, there are demanding working hours (shifts) and the social status of the work is relatively low. Moreover, there is a widespread use of part-time, temporary and zero-contract positions and a high sick leave percentage $[16,17]$. At the institutional level, this situation may lead to problems with recruiting and retaining qualified employees in the care sector in the longer term, while at the individual level, the worker in such a situation leads to the constant "shopping" for shifts in order to make a living wage. This may subsequently result in choosing a different line of work.

In Norway, there is a strongly gender-segregated labor market where women dominate public sectors such as health, education and social services while men dominate private sectors such as finance, construction and manufacturing [18]. Care work has been and continues to be dominated by women $[17,19]$. Altogether, $88.7 \%$ of ethnic Norwegian care workers are women as compared to $80.6 \%$ of the immigrant workers [12]. Compared to ethnic Norwegian care workers, the workers with an immigrant background are younger and have less formal education [20]. This contrasts with what Orupabo and Nadim [18] observe in the cleaning industry. They found that there has been a shift in the evaluation of skills and the 'suitable worker' which has led to gender desegregation in the cleaning industry in favor of male workers, and at the same time, ethnic segregation favoring immigrant men.

In Europe, there is a rapid increase in precarious labor, i.e., work situations characterized by exploitation, inadequate legal protection and wage conditions [21]. This situation is caused by the transition to 'flexibilization' as the dominant mode of labor [14]. Certain groups of workers might be preferred by employers because of their 'exploitability' [21-23]. The many examples of such changes in work-life combined with increased deregulation of work observed in Norwegian society over the last five to ten years are indicative of new labor relations with the potential for creating precarious employment situations [22]. Like the hospitality industry, the care services flag flexibility as the key characteristic of their 'trade' because of the 24/7 need for labor, and therefore claim to be dependent on a 'surplus-pool' of workers ready to serve. Additionally, like the hospitality and cleaning industries, work in the health and care sector is increasingly characterized by an intersection between the categories of gender and migrancy [17]. When we observe a clustering of immigrants into specific occupations and/or industries, we can claim that an immigrant niche is established [23]. Yet, how and why such niches occur in the labor market, and what dynamics contribute to its (re)production are much debated questions in the research literature. Friberg et al. [23] (p. 323) tie the formation of immigrant niches in the labor market in Norway to class dynamics and the wider institutional landscape of the welfare state. They pinpoint that as the native-born population is increasingly wealthy, highly educated and 
socially protected and, thus, in a position to 'withdraw' from work in the lower tiers of the labor market, the immigrant population increasingly seem to take over labor in " ... the lower tiers of many traditional working-class industries ... " [23] (p. 323). This means that the decline in supply of native-born workers to these industries (cleaning, hotel, fish- processing) reduces the competition for work here and opens up for immigrants' entry into the labor force. In other words, immigrants are often offered, and take on, work that native-born workers increasingly reject. However, the increase and presence of immigrants, often stereotyped as more willing and docile than native-born workers, contribute to 'cement' this work as 'low status' which, over time, leads to its being labelled as 'immigrant work' [19] (p. 3). In this study, we claim that care work has become an entry-level occupation for immigrants as cleaning and hospitality work has been for a couple of decades, and that clustering of this group here indicates the emergence of a new immigrant niche in the labor market. In Norway, employment hierarchies and immigrant niches are well-documented in the cleaning, hotel and fish-processing industries $[19,23]$. We hold that a new immigrant niche is emerging in the lower tiers of the long-term care 'industry' and we aim to show that the lengthy process of training and formalizing qualifications combined with labor market characteristics of LTC contribute to produce this niche.

From its inception in the 1990s [24], intersectionality has developed from a theoretical framing focusing on individual identity/'who people are' into a perspective and a methodology oriented towards exploring dynamics of difference and sameness from the individual to the institutional level (at different analytical levels) $[25,26]$. The widening scope of intersectional scholarship has, amongst others, produced studies that try to capture contextual dynamics of power where the emphasis is on structures of inequality rather than on categories of identity. In other words, it concerns "the way things work rather than who people are" [25] (p. 797). In order to understand patterns of the privileged and the non-privileged (or advantaged and disadvantaged) at the nursing homes in this study, we place our discussions within the wider frame of labor market trajectories and work organization in the long-term care services. Our motivation is to understand both workers' experiences and the dynamics of power shaping these experiences. We thus adopt an intersectional 'process approach' analyzing experiences and trajectories "within the context of societal structures and managerial practices" [26] (p. 712).

This article is based on interviews and focus groups discussions with employees at nine Norwegian nursing homes and discusses the organization and practices of training new employees in relation to workplace inclusion and work life experiences. The aim of the article is to illuminate work organization and practices within a system that needs workers twenty-four hours a day. We argue that these practices maintain advantages and disadvantages related to whether staff are permanently or temporarily employed, or hold full time or part time positions (despite new members of staff being required to play a full-time role). We address both the demand and supply side of labor relations but focus primarily on the supply side through immigrants' workplace experiences in a strongly gender-segregated and hierarchically ordered Norwegian labor market [19,23].

\section{Norwegian Long-Term Care and Immigrant Workers}

In the literature, Norwegian long-term care is placed within the Nordic welfare model, characterized by universalism, governmental control, tax-financed interventions and welfare programs $[27,28]$. Nursing homes constitute a principal public care alternative and are regarded as vitally important, particularly for the oldest citizens with advanced chronic illnesses and multiple diagnoses. Studies have demonstrated that service recipients in long-term care are increasingly frail older people characterized by multi-morbidities, cognitive failure and polypharmacy [29].

The current needs of the service recipients place greater demands on both the organization and management of the services and on the competence of the staff. The service is vulnerable without sufficient and suitably qualified staff, and the quality of the services depends both on the structural conditions for the organization to provide services and on the employees' qualifications, knowledge and attitudes. Both the capacity and quality of service provision is affected by a care staff's skills and 
knowledge. Staff in nursing homes include auxiliary nurses (largest group), registered nurses who often assume the leadership of the wards and finally, low-skilled assistants [16,17]. In order to work in Norway as, e.g., a registered nurse or healthcare worker, an immigrant must obtain authorization from the Norwegian Public Office for Healthcare Professionals (SAFH). Candidates with an education from an institution within the EU are automatically acknowledged as qualified, while candidates with an education from other countries are often turned down by the SAFH and work in lower positions than would be indicated by their education [30]. They can take supplementary exams or collect "hours" of work experience to be recognized as formal carers.

Multiple factors challenge the reception of immigrant workers in LTC. Linguistic barriers and challenges related to cultural diversity are discussed in several studies [31-35]. Language (proficiency) is regarded by both the national authorities and the care sector as an integral aspect of care work, and mastering the language is seen as necessary to be able to provide good quality care. However, several studies have concluded that developing communicative skills is demanding and stressful, both acquiring pure language skills and learning about a new way of practicing and caring [36]. Communication is further complicated when the persons in need for care suffer from illness and have reduced communication abilities [35,37]. Cultural differences between patients and providers can greatly influence the ability of the migrant carer to offer adequate care [38]. Communication difficulties can challenge both patient safety and quality of care services, and prejudice, stereotyping and lack of awareness to training (as seen in our study) can challenge good working environments and workplace inclusion of immigrants [38-40].

Often immigrants struggle to gain access to working life, and experiences of stigmatization, discrimination and exclusion are reported [4,41-43]. Other obstacles for immigrants in employment relations include lack of support from managers or colleagues at the workplace, and a lack of formalized and organized follow-up and training from the organization and/or management. In addition, they are subject to stereotyping such as being more hard-working, docile and willing to work in more substandard conditions $[19,23,44]$. Another complicating aspect related both to communication and care work in nursing homes concerns knowledge acquisition based on 'non-formal learning', 'implicit learning' or what is referred to as 'tacit knowledge' $[45,46]$. So far, little research has been conducted in these fields targeting formal and informal training procedures as well as intracollegial procedures and relations at the workplace for new employees with an immigrant background. The aim of this article is, hence, to explore this field and question: Which systems and organization of training is offered to new employees with an immigrant background and what are the attitudes towards immigrants in this setting? How do immigrant workers experience their introduction to work and what characterizes the shifts they carry out? What are perceived by majority staff and management as integral and indivisible aspects of care work for which the immigrant workers must qualify?

Before we present our results, we will introduce intersectionality as a theoretical lens for discussing our material.

\section{An Intersectional Approach to Labor/Care Work}

Crenshaw's (1990) research [24] on black women's experiences of discrimination in employment in the US contributed to a move in feminist scholarship from a single axis of analysis (gender) towards a multiple axis analysis-i.e., focus on the ways gender is interlocked with other social categories of difference such as ethnicity, migrancy, race, sexuality, age, nationality, caste, etc., in the production of oppression and social inequality. Scholars have further developed intersectionality studies in a range of different directions, at different levels of analysis and in different thematic areas [25,47]). The use of intersectionality as a theoretical framing aims at revealing differences and tracing the ways these are symbolized, articulated and practiced, in addition to analyzing how they "produce patterns of equality and inequality, dominance and subservience, in particular social contexts" [26] (p. 710). Although there is some tradition within the study of labor to explore the interlocking of class, race and gender, the perspective is underused and carries a greater potential in studies of employment and 
labor relations [47] (pp. 232-234). In this study, we explicitly focus on the interlocking of gender and migrancy [39] in order to analyze the work experiences and labor trajectories of immigrant staff at nursing homes within the broader context of the Norwegian welfare state.

Theories of intersectionality emphasize that the human experience is complex and consists of "multiple layered identities, derived from social relations, history and the structures of power" [24] (p. 9). Intersectionality posits that an understanding of a person's social location, i.e., his or her place in society, is essential to capturing the complexity of a person's experiences, including his or her actions, choices and outcomes [48]. In this context, oppression is understood as a system that maintains advantage and disadvantage based on a social group membership and operates intentionally and unintentionally on the institutional and cultural levels [48]. Oppression is not understood as a tyrannical power that is coercing people, but as "everyday practices of a well-intentioned liberal society where... certain groups are denied full rights and opportunities to participate fully in society." [49] (p. 41).

In the context of the labor market, rights and opportunities can be blatantly denied or emerge more subtly [50]. For example, in the context of the nursing home, what attitudes, values and norms come into play in relation to obtaining advantages, and what lines does the distribution of advantages follow?

Our ambition is to use intersectionality as a theoretical lens is not to understand immigrants' individual identities, or the heterogeneity amongst immigrant workers, but rather to explore and analyze how organizational processes in the specific context of Norwegian nursing homes can reveal structures and forms of organization and practice that shapes inclusion and exclusion/oppression and privilege at the workplace. The focus on processes contributes to insights in diffused systems of interlocking oppressions that may marginalize groups of workers at a workplace, and intersectional process models will focus on the context rather than on individual identities in analysis of such an issue [26] (p. 712). We are interested in how power operates in the workplace and how interconnections between axis of difference produce privilege and/or oppression at the nursing home workplace. We thus take an 'inter-categorical' approach rather than an 'intra-categorical' approach (which focuses on individual identity). We aim to reveal differences between different groups of workers, where processes, not individuals, are at the center.

\section{Method and Data}

A qualitative study was designed by the authors and discussed in the research group for a larger research project, "Multicultural workforce in Nursing Homes: Contemporary challenges, opportunities and potentials for the future in the Norwegian municipal care sector."

Qualitative interviews are preferred in accounts of realities and experiences that are personal and complex, evoking feelings and reflections and were carried out in two nursing homes. Focus group discussions (see below) were in arranged with participants from additional seven nursing homes.

The design and purpose of the study was discussed with the Centre for Development of Institutional and Home Care Services (USHT), a resource center for LTC services contributing to service development. USHT also helped in recruiting nursing homes for participation and made the initial contact by presenting the study to the managers in the selected nursing homes. Interview guides were drafted and discussed in the research group, USHT, and shared with a Regional Ethics Committee and the Norwegian Social Science Data Services for comments.

\section{The Interviews}

Between December 2017 and June 2018, 30 interviews were carried out in two nursing homes. Staff at all levels, both Norwegian and of an immigrant background, from registered nurses, auxiliary nurses in full employment to low-skilled substitute or temporary workers with low FTE percentages were included. Seventeen participants were of ethnic Norwegian background and 13 were immigrants. All participants were informed at a weekly staff meeting about the study and could ask questions and express opinions. Afterwards, members of staff were asked to be interviewed, and signed a consent form. 
An individual interview lasted from 40 to $70 \mathrm{~min}$ and took place in an available room in the nursing homes. All respondents allowed the interview to be recorded provided they remained anonymous in any written reports. Prior to the interviews, a semi-structured interview guide was developed and tested for suitability. Small adjustments mainly related to the rephrasing of questions. The final guide consisted of five main thematic sections: work experience and training, language and communication, relationship to other staff and to management, contact and communication with the residents and finally, contact with next of kin.

\section{Focus Groups}

In addition, four focus group discussions were held with immigrant workers with no formal care education employed at seven additional different nursing homes. The participants were all attending a course arranged by the municipality to improve their care qualifications at the time of the focus group. They were asked to participate in the focus groups and signed a consent form.

The focus groups involved, in total, 21 participants (4 men and 17 women) divided in groups with 4 and 7 participants per group. The participants were from 23-51 years old and came from countries in Africa, Asia, the Middle East and Eastern Europe. The length of their work experience in Norwegian long-term care varied between 2 months and 18 years. A few participants had a technical education at master or bachelor level from their home countries; others had completed secondary school while others had no schooling or education after elementary school. The participants in this survey spoke Norwegian at varying levels ranging from fluent to limited speech. At the start of the focus groups, the moderators spent time establishing a good connection with the participants. Everybody was encouraged to voice their opinion and share experiences. The moderators strove to frame questions ensuring that all participants had understood the content. The participants were given time to talk at their own pace, and the moderators asked questions to ensure correct understanding of opinions given.

\section{Analysis}

All interviews were carried out by the first author. Interviews were audiotaped and transcribed verbatim to ensure that the information was as correct as possible. Sections of interviews had to be omitted in a few cases, as it was difficult to fully understand what was said even after rephrasing of the questions in the actual interview. The first author shared the content of the interviews and discussed these in the research group and with the second author. Staff interviews across positions and locations were compared.

In line with thematic analysis, the transcripts were read several times to gain a thorough overview and understanding of the data, looking for patterns and emerging themes [51]. Sections relevant to the topic of systems surrounding training procedures and employment trajectories, attitudes towards immigrants, working conditions and characteristics of the shifts carried out, and tasks perceived as integral and indivisible aspects of care work were identified. Training and training experience emerged as a main finding that decided whether staff received collegiate support or became isolated. This impacted on whether staff felt advantaged or disadvantaged; if staff experienced stability in the shifts allocated to them, they were able to obtain sufficient knowledge about the residents, thereby increasing the opportunities to do a good job.

Quotes used for the article were translated from Norwegian into English by a professional translator and this work needed special attention and time to ensure that meaning and content were kept as presented in the interviews.

\section{Ethics}

The head nurse first informed all participants in the two nursing homes about the study at their workplace. The staff were asked whether they were willing to participate. After giving a positive response, the researcher was introduced to the staff at a meeting to further inform them about the study and to allow them to ask questions and express opinions. All staff present in both nursing 
homes agreed to be interviewed. Before the interviews commenced, the study was approved by the Norwegian Social Science Data Services (53138). The project was also discussed thoroughly with the Regional Ethics Committee. For the interviews, all participants provided their informed consent to participate and were informed about their right to withdraw from the study without stating a reason.

\section{Results}

\subsection{Three Shifts of Training and Good to Go}

The regular norm in most nursing homes (NH) in Norway is that new staff, ethic Norwegian or immigrants, are given three shifts with training before they start to work independently in regular $\mathrm{NH}$ operation. Some of the new staff members in our study had no previous education or work experience prior to starting to work in long-term care. Some had a completely different background, e.g., from technical or administrative fields and education at university level in their home countries, but no working experience from care work at all. One immigrant who worked as an assistant exclaimed in the interview how she had repeatedly reminded her new employer that she had no care work experience when she signed on as an "on-call assistant". She felt there were many new things to learn and she was concerned about how she would be able to acquire sufficient knowledge:

"I said to them [management of the nursing home] that I was new in the job. I used to be a secretary, and now I've transferred to a different professional area-health and care work. It's completely new for me and I started from scratch ... so I have to ... be able to ask in order to learn things. Every time I come across something that's new for me, I have to ... ask." (Female, assistant employee from Africa, $49 \mathrm{y})$

Several staff members of both immigrant and Norwegian/majority background were critical of the short training period of three shifts they received. After the training shifts, it was an unwritten rule that the colleagues with more work experience would take care of the new staff and prolong their training. However, if staff on the same shift were reluctant to help the untrained staff, it could be problematic to ask questions when not knowing how to carry out a task. An on-call migrant LTC worker exclaimed:

"I didn't know what I should help with, and I took part in three training shifts ... After that I had to start working full out, and not all my colleagues smile and are patient! Not at all! I was told I was incompetent when I started, and I was! We need to know, but we don't know ... I felt after three shifts that I had no knowledge. Someone who's been working there for ten years will quickly see that I'm incompetent and uncertain. I have no knowledge, but that's quite natural after only three shifts!" (Female, on-call assistant, Eastern Europe, 35 y)

Her experience was that permanently employed colleagues were gossiping about untrained staff and temporary workers and trying to exploit their lack of knowledge instead of helping to train them. In her unit she experienced that:

"Those who were competent went around talking about others behind their backs, and exploited their [the substitute's] incompetence, and pointed out mistakes all the time. But they didn't understand that we couldn't possibly know everything, that there's such a lot that's new!" (Female, on-call assistant, Eastern Europe, 35 y)

Similarly, an older ethnic Norwegian nurse had recently discussed this concern with her colleagues in the nursing home, which was trying to recruit temporary workers for the summer. They had five migrant workers who were on training. One young man from an Asian country was discussed among the staff and described as hopeless, especially his behavior towards the residents. He had, for example, entered a resident's room one morning and started to talk loudly about where he was from and what it looked like in his home country. The resident had become furious and other staff had to come and help 
the resident to calm down. The older nurse explained that they had a meeting in the unit afterwards and she got very upset, claiming that permanent staff had to take more responsibility in training new staff:

"Everyone complains that new people who begin here don't do their job. Then I said that we could turn this around: "Do we do our job in relation to training? Do we teach them what we ought to? How they should do things? Are they clear about their own tasks, and have we informed them clearly enough? Do they know how we should act when we're in the bathroom together with residents? How do we talk to residents?" Then there was silence. We're the ones who give them inadequate training. It's us. Everything you blame others for can rebound on yourself. There was complete silence." (Female, head nurse, Norwegian, $61 \mathrm{y}$ )

\subsection{Willful Ignorance}

Another immigrant LTC assistant had experienced that some of the permanent staff took time to show new staff how to do various care tasks, while others did not care at all and would rather: " ... go and tell you how low-skilled you are instead of helping. I've heard expressions like this several times: "She has no business being here, that ... [swear word]. She's no good at all." (Female, assistant, Africa, $27 \mathrm{y})$.

Several of the immigrant LTC workers staff had experienced situations where they lacked training, and instead of being taught how to do the job if they did it wrongly, they had experienced being ignored or "frozen out". One LTC immigrant worker who had worked in several nursing homes had observed that many situations and disagreements were not resolved, but dragged on:

"Here in Norway, it's against the law to gossip about others. But there's such a lot of hypocrisy and that's a problem. In my country we just say directly to the person: "I don't like you!" And we talk about it and get the chance to change it. Then we're finished with it, and we carry on working. And we find out what we should do and how to solve the problem. It's different here. Nothing is said directly ... but it's in people's thoughts for a long time ... You're ignored! It's unfair and unpleasant ... We can take a break and talk about it in my country, and then we're finished with it. We should do it that way here [in Norway] rather than think "How am I going to tackle working with him or her?" It causes frustration, and if there are tensions between people, the work isn't completed properly." (Female, assistant, Africa, 51 y)

This section brings attention to situations of being willfully ignored and, as a consequence, staff are kept in a position of uncertainty and not knowing how a care task should be carried out. The system of organization of training offered to new employees with a migrant background is limited, and how training is followed up after the initial training shifts is not systematized.

\subsection{Access to Information and Understanding Work Tasks}

A young migrant worker pointed out that staff members had different ways of carrying out the care tasks they demonstrated to newcomers. After the three training shifts, she felt confused and could not sort out which approach she should choose herself. In addition, she felt a constant need for more information:

"During the training shifts, there were also different people on duty. They do things in different ways as well, we don't learn everything. There's an awful lot of information, and situations arise all the time when you think "What should I do now? Shall I run around looking for a nurse when I know that they're busy as well or shall I try to solve the problem myself?" (Female, auxiliary nurse, Asia, 28 y)

She experienced that some staff members were usually helpful and friendly, taking their time to explain, while others were stressed and did not really give a proper reply when asked a question. Sometimes, the pace at the nursing home did not leave much time for asking and answering questions 
because time was too scarce, and the care needs of the residents could change from one moment to the next. This meant that new staff faced dilemmas in terms of what action they should take. If they chose to pose a question to more experienced staff members, they would inevitably interrupt these colleagues and the residents they were caring for at that moment. On the other hand, they could try to find out by logging on to the computer system, but this would take considerable time and they would have to leave the unit. A third option was to try to ask the residents themselves for clarification. A temporary worker claimed, however, that this was "dangerous", as most of the residents suffered from dementia, and the information they could give was not trustworthy. A typical example of the latter was residents who asked for medication, or extra medication, and who would get very upset if refused medication. The temporary worker would have to contact the registered nurse in the unit who had responsibility for medication that day to find out. The residents could get very frustrated if they felt that the staff on the unit did not have the information they ought to, or they were uncertain about work procedures:

"And it's difficult not knowing what to do. I might be stressed and make mistakes and it's not safe for the patients either because I lose my overview. Some of the patients are confused and you can't listen to them. Nor are all patients able to let you know either ... for example, that they don't use that cream any more ... and then I become even more uncertain and I don't like that ... I think things must be clear! ... It's important to know what to do. When we talk to old people, they're a bit sensitive and we must do everything correctly and preferably straightaway." (Female, on-call assistant, Eastern Europe, 35 y)

In the interviews, the participants were asked which tasks they liked most and least. Most of the employees spontaneously claimed that all the care tasks were a part of their position, so they did not differentiate between various tasks in that way. However, several participants stated that being clear about the tasks was the most important aspect:

"I don't want to talk about what I like and don't like to do. That's not what it's about ... but I must have a clear idea of what the task is, know what the goal is and why. It's often the task that's unclear. For example, who's supposed to attend to the different patients. Sometimes it's a doddle but at other times not. Then there's a lack of cooperation between me and my colleagues since I'm the assistant and lack knowledge and information." (Female, under formal training, Eastern Europe, 42 y)

This led to situations where the temporary staff were dependent on the permanent staff for updated knowledge and information about the residents. The permanent staff could sometimes become irritated because they might feel that they had to work more, and step into situations where the substitute workers could not sort things out by themselves.

\subsection{The Virtue of Intimate Knowledge for the Provision of Adequate Care Services}

The migrant workers equated the role of being a temporary worker or a substitute with a lack of continuity and being unable to stay on top of the residents' shifting care needs. To know the residents, family, background, former occupation, interests, etc., and to have detailed knowledge of their care needs is regarded as a virtue among the majority staff and described in interviews as key for one's ability to provide quality care. Several immigrant workers struggled to get enough information about things and tasks they should do at work. Many of them were filling staff gaps at different units and did not have the opportunity to keep track of the same residents from day to day in the same way as regular staff. Changes happened frequently to the residents. One immigrant LTC assistant said:

"I work in different units, and I've maybe not seen the patient for a long time, and then there's a lot I wonder about. I must leave them and run around and ask. Should I go on the computer and search there? Or should I ask? I don't like that. I like to know!" (Female, assistant, Africa, 29 y)

Another LTC immigrant worker stated that this is the nature of being a substitute: 
"You don't really know what's going to happen that day. One day I'm in one unit, the next day in another and the third day maybe in a completely different unit ... I have to work just as independently when I'm a substitute." (Female, substitute worker Africa, 23 y)

This makes an interesting contrast to the interviews of the permanent staff (mostly ethnic Norwegian) where personal knowledge of the patients was repeatedly mentioned as an important source of success and quality of care work. An experienced registered nurse claimed that in order to provide good quality care:

"You have to know the resident well. It's all about this, and you need to know what to talk about with them! ... Those with a minority background often have part-time positions, and they work in the whole institution to a much greater degree that the rest of us [permanent staff] so knowledge of the patients is a challenge. They have 24 patients they have to know well, and that's not easy when you have a part-time position. In comparison, I have the main responsibility for knowing 8 patients well." (Female, registered nurse, Norwegian, $38 \mathrm{y}$ )

A LTC immigrant worker listed the challenges she faced in doing her job as a substitute as a combination of a lack of skilled knowledge, inadequate information about residents, and poor understanding of the language and culture:

"There's a lot of things I need to know. Language, communication with people who're old and sick. I lack knowledge as an auxiliary nurse because I'm low-skilled, but despite this, I'm made responsible for the residents every time. I think about the safety of the patients! Both for them and us-we don't do a good job for the patients. It takes longer. I must spend time finding out what I'm supposed to do. And the insecurity means that I automatically do a poorer job." (Female, on-call, Eastern Europe, $35 \mathrm{y})$

Permanent staff worked in the same unit and had education, thorough knowledge about the residents and the daily changes in their health and care needs. They claimed that temporary workers lacked all these prerequisites for doing a good job. A Norwegian-born registered nurse in a permanent position exclaimed: "It's not just a matter of coming here every third weekend", thus indicating that continuity is an important dimension in the quality of the care work.

\section{5. 'Just an Assistant'- Collecting Hours}

Some of the immigrant workers who participated in interviews had experienced situations where they felt they had to do more work than other members of staff, or they were assigned tasks that others did not want to do. However, it was difficult to go to the manager to talk about this issue. A young immigrant worker in a temporary position felt it was risky to approach the management:

"I don't dare tell my boss that such and such a person isn't working, because then my boss might tell them that I had said that! I tell myself that I don't have a permanent job in Norway, I'm just a substitute and I must do what I'm supposed to and that means working without saying anything about other people. I go home to my husband and complain and ask "Why?" [She cries and laughs in turn]. But next day I go to work again. I tell myself that it's fine. One day I'll have a permanent position! I won't always be a substitute and have to ... put up with everything." (Female, on-call assistant, Africa, 28 y)

Several of the ethnic Norwegian staff claimed that immigrant workers seldom raised issues for discussion. They were mostly seen as quiet and only occasionally raising their voice in meetings. An ethnic Norwegian registered nurse said that the LTC immigrant workers were generally quiet and never complained: 
"Staff with minority background are very conscientious ... they don't say so much about what they wish for ... They take the shifts they get, and accept that." (Female, registered nurse, Norwegian, $57 \mathrm{y})$

The exception was some of the permanently employed immigrant LTC workers who had considerable work experience:

"Employees with a minority background seldom say a lot ... They say "Yes", so that's OK. But in my view, they must have thoughts about things as well? But they don't put forward their wishes, they accept a lot. I don't know ... they come from different cultures and maybe it's not usual to put yourself forward and say what you think or want, but none of them come to us and say "No, now I'm really tired." No, that doesn't happen! But I imagine that they're just as tired as the rest of us. Maybe some are even more exhausted." (Female, registered nurse, Norwegian, 38 y)

An ethnic Norwegian head nurse claimed that she never got a "No" for an answer when she asked a migrant worker to take an extra shift. The head nurse was puzzled by this as many of her employees with a migrant background had young children at home, but children's illness or not being able to find a babysitter was never among the reasons she heard from immigrant workers for not being able to work a shift. She said she had discussed this with those concerned.

Several of the participants spoke of themselves in the interviews as 'just assistants', and they felt that because they had not completed their education, they had to keep quiet:

"When you're just an assistant and haven't any professional training ... you can't say anything, and you must be very careful and calm and... Yes. And even though there's mutual respect... so I haven't had any problems up to now, but... Yes, I must be careful." (Female, under formal training, Middle East, 34 y)

The management at the nursing homes stated that they could use the distribution of work shifts among substitute workers as a tool in managing their team. One way of phasing out unwanted substitute workers was to cease giving them shifts. In a similar way, the management could steer how long it would take a substitute to become a certified auxiliary nurse. In order to be certified as an auxiliary nurse/healthcare worker, the candidates needed $5000 \mathrm{~h}$ of work practice-and how long it took to obtain these hours was dependent on the numbers of shifts given.

A migrant worker, who had almost reached the number of hours required, was feeling frustrated about not getting enough shifts to get certified:

"I am not allowed to take the tests for getting certified before I have sufficient hours of work experience. I wish I was given more shifts so I could finalize ... I think it is a bit unfair, as I won't get a full-time job before I get certified. I wish the head of the unit considered this, but I do not know how she thinks." (Female, under formal training, Middle East, 41 y)

To summarize, this section brings attention to the fact that low-skilled immigrant workers could be reluctant to raise issues at their workplace and voice their opinions. Staff with immigrant backgrounds were often willing to take on extra shifts, and many also need extra hours to obtain formal qualifications.

\section{Discussion}

Immigrant care workers often presented themselves as feeling privileged when they got the chance for a better life in Norway after having escaped war, poverty or disadvantaged lives in their homelands. A good income, workers' rights and feeling safe were appreciated values. However, this feeling of privilege among the immigrants had a flip side. Immigrant workers were concerned about not getting enough training and claimed it was difficult to raise questions at work and ask for clarifications. They often filled in at several wards, making it hard to stay updated on residents' changing care needs. 
They also had to learn work procedures at different wards. Permanently employed staff holding high percentage positions argued that "everyday contact" was a prerequisite in providing good quality care. This implied seeing the same residents and receiving daily information, being updated and having a general overview of the ward. Substitute workers, workers with low percentage positions and immigrant workers with no formal care skills had less chance of obtaining this advantage, and it can be argued that these issues kept them in low-rank positions in the nursing home, reproducing their disadvantaged position. When being constantly 'on the move', it was more difficult to connect with the staff at the various wards and to be confident enough to ask questions about care and residents. It is obviously not the goal at these workplaces to keep certain groups of staff at the bottom of the hierarchy, but our findings shed light on unintentional effects of everyday workplace practices (such as staff being constantly on the move and filling gaps at various wards) which distribute advantages and disadvantages within a system $[49,50]$. Research on workplace discrimination shows the need for future studies to look at subtle forms of discrimination [52]. Less visible and unintentional acts, such as retaining the distribution of knowledge among a few nurses and structural process that legitimize forms of power, might be just as harmful as blatant discrimination.

Studies of intersectionality stress the interlocking of class, race and gender in understanding patterns of equality and social inequality [26]. Norwegian nursing homes are almost fully staffed by female workers, and care work is feminized [14,19]. Previous studies have documented that international care staff who have qualifications on arrival, strive to get this recognized in Norway [30,53]. For example, staff holding diplomas as registered nurses from abroad (especially outside of the European Union) are approved in Norway as auxiliary nurses, which is a lower qualification [53]. The empirical material in this study questions the negotiating power the group of immigrant care workers possess when striving to get qualifications. For example, low-skilled staff need a certain number of shifts to get enough hours to qualify as skilled workers. Unless they are skilled, they cannot get a permanent job. Previous research has also discussed the fact that employers see immigrant workers as more hard-working and committed [19]. For example, Van Riemsdijk [54] shows that care workers from Poland have a reputation for their better work ethic and being less demanding than Norwegian care staff. Likewise, our material shows that immigrant care workers are seen as more willing to work and that managers never get a "no" for an answer when asking an immigrant worker to step in and take an extra shift or fill gaps at units due to sick leave. To the managers, some of these employees turned out to be the 'saviors' of the nursing homes in times with many of the permanent staff being absent. Short shifts $(5 \mathrm{~h})$ were usually considered less attractive among staff, but managers reported that low-skilled migrant workers were generally willing to accept these shifts if asked. This indicates that immigrants, in a sense, are more 'exploitable' as workers, and that they, for this reason, end up in more precarious labor situations. We have aimed to reveal the ways 'difference' plays a role in labor experiences at these nursing homes: the ways difference is articulated, what kind of effects it has on labor trajectories, and as described above, we see the conjoining of gender and migrancy producing inequality and 'oppression'.

In our study, immigrant assistant staff was in a precarious situation, where turning down shifts would mean that they would spend (even) longer time acquiring qualifications. Some staff collecting hours could complete the process in three years while others could take more than five years, all depending on the availability of shifts or how the management distributed the shifts among the staff. In the introduction, we discussed 'flexibilization' and the ongoing processes in employment that allow for increased use of temporary labor, part-time employment and zero-hour contracts [21,55]. The use of part-time and on-call labor is widespread in LTC, comprising both ethnic Norwegian and immigrant workers [23]. On the one hand, the LTC staff are protected by workers' rights-rights that were mentioned by several of the participants in this study. On the other hand, the material in this study also shows that temporary workers lose out on continuity of care and updated information about residents when they are sent around in different units to fill care gaps. Moreover, immigrant workers tend to accept all shifts offered in trying to qualify for a permanent position-a lengthy process of 
qualification keeps them lowest in an employment hierarchy, filling a niche that resembles what is observed in the cleaning, fishing and hotel industries $[19,23]$. This indicates that the interlocking of gender and migrancy is also a mechanism in the emerging immigrant niche at the lower tiers of the healthcare sector, as the above illustrates. Dynamics at the workplace might restrict the immigrants' mobility in the system.

Increased complexity of care tasks in long-term care as discussed in the introduction further fuels the need for more competence and in-depth knowledge about the residents and their needs. As shown above, familiarity with nursing home residents was held by the ethnic Norwegian workers as one of the key virtues of quality of care, and it thus represents something immigrant workers must strive to achieve in order for them to be able to deliver the same 'quality' of services as the majority workers. In a busy workday, when they were 'just an assistant', the immigrant workers found there was little time to acquire this information. This was perhaps also accentuated by the practice of 'willful ignorance' by majority staff which entailed that information and correction were not given, although it was recognized that it was needed. It can be argued that such practices, within a system that needs workers $24 / 7$, maintain the relative advantages and disadvantages related to staff being permanently or temporary employed or in positions with high or low percentages, and reflect negatively on how immigrant staff are trained to assume a full role.

This leads us to argue that low-skilled staff can enter either positive or negative spirals at work depending on the management and the institutional culture at the nursing homes. Negative spirals at work may develop as workers with an immigrant background fare worse in several respects than those native to Scandinavia or other parts of Europe. This results in immigrant LTC workers who are less engaged and voice their thoughts to a lesser extent than those native to the country [56]. Management lacking multicultural knowledge and training in intercultural relations might be especially vulnerable in not being able to understand and 'build' their multicultural staff and assist them in acquiring formal qualifications. With this in mind, there are demands for courses, competence-raising measures or bridging programs for employees of immigrant backgrounds to facilitate an adaption to working life abroad [38,57]. Formal courses do exist in some countries, such as, for example, transition courses for internationally qualified registered nurses (IQRN) in Australia and New Zealand [38]. In Norway, the health authorities have aimed to increase the number of auxiliary nurses to prepare for the demographic change requiring more staff with better qualifications in the care services. The authorities offered the municipalities funding for 2014-2016, for projects helping low-skilled migrant staff to obtain formal qualifications, e.g., as auxiliary nurses. Several pilot projects concluded that a special approach was needed for this group, addressing particular cultural dimensions of care and communication more deeply [58].

\section{Conclusions}

In this article, we have described the increase of immigrant labor in nursing homes in Norway and discussed this as an emergent immigrant niche in the lower tiers of the long-term care 'industry'. We have argued that this niche seems to be (re)produced through a complex range of processes, and discussed workplace practices such as the system of training at the NHs, access to information and ways of sharing information. We have also focused on the importance of intimate knowledge about residents for the quality of care, as related to immigrants' workplace experiences. Such practices maintain advantages and disadvantages based on staff being permanently or temporary, employed or having full time or part time positions. The lengthy training for formal qualification as a healthcare worker, and majority employee practices of 'willful ignorance' further add to the reproduction of an employment hierarchy that puts immigrant workers and other employees in low FTE percentages in vulnerable labor situations. We have shown that the training of new staff and immigrant workers is limited to a few shifts. Subsequently, this depends on the management and the 'culture' for training new staff at the workplace. While much knowledge can be passed on by giving information and practical training, we also found that some knowledge is tacit and needs to be gained by spending 
enough time with residents. Permanent staff working full-time acquire this information by being employed at a certain ward while part time and substitute workers with little training circulate to cover absent staff.

Using an intersectional process approach, the article has examined work experience and structures of opportunity in the labor market through a focus on the intertwining of categories of difference that potentially can contribute to the production of inequality. This means that in our discussion of the formation of new divisions of labor and new employment hierarchies in the long-term care services, we have analyzed the intersection of gender and migrancy as it articulates in the nursing homes as workplaces, and found that this interlocking does position immigrant workers at the lower end of the hierarchy. 'Difference' is understood as being dynamically articulated, and the meaning of difference is context specific as, for example, the nursing home as a workplace located within the larger context of the long-term healthcare sector [26] (p. 714). Thus, we have aimed to show the ways "difference is enacted through performance norms, at ... organizational level" [26] (s. 714) at the nursing homes. This enactment gives shape to different work experiences and thus, also to different labor trajectories that for some immigrant workers are precarious.

The current healthcare policy vision of creating sustainable care services by way of recruiting unskilled workers into the health sector by directing them towards care should be studied more carefully, also from ethical points of view. The recruitment initiatives stem from states that desperately need more care workers, and it can be called into question how this recruitment is able to take care of vulnerable workers and the equally vulnerable elderly in need of care. Increased focus needs to be placed on organizational conditions, diversity management and inclusive management styles [59], training for the wider workforce as well as migrant workers through the development of career pathways [2]. This might also help healthcare workers to thrive in their jobs and continue working and building competence in the long-term care sector.

Author Contributions: Both authors contributed to the conceptualization, outline and design of the article, and both authors wrote the paper. L.T. collected data and shared the transcribed data with A.F. for analysis. L.T.; methods and results, A.F.; intersectionality and labor market-with significant input from each other. Both authors analyzed the data and discussed the results. Both took part in the revision and editing of the article, and L.T. had the main responsibility in revision and in contact with the publisher. All authors have read and agreed to the published version of the manuscript.

Funding: This research was funded by the Research Council of Norway (RCN), grant number 256617.

Acknowledgments: This article forms part of a larger research project 'Multicultural workforce in Nursing Homes: Contemporary challenges, opportunities and potentials for the future in the Norwegian municipal care sector'. The authors would like to thank the informants for their contribution to this study by sharing their work experiences. Many thanks to Prof. Charlene Harrington, University of California, San Francisco, for valuable comments to earlier drafts of this manuscript. Thanks also to the USHT for assistance in organize focus group discussions. Finally, many thanks to the three anonymous reviewers and to the editor of this Special Issue for providing constructive comments that helped to improve our article.

Conflicts of Interest: The authors declare no conflict of interest.

\section{References}

1. Groenou, M.V.; De Boer, A.H. Providing informal care in a changing society. Eur. J. Ageing 2016, 13, 271-279. [CrossRef] [PubMed]

2. Hussein, S.; Manthorpe, J. An International Review of the Long-Term Care Workforce. J. Aging Soc. Policy 2005, 17, 75-94. [CrossRef]

3. Klassekampen. Vikarbruk [The Use of Substitute Workers]; Klassekampen AS: Oslo, Norway, 2019.

4. Dale, R.; Seeberg, M.L. “Does she speak Norwegian” Ethnic dimensions of hierarchy in Norwegian health care workplaces. Nordic J. Migr. Res. 2013, 3, 82-90. [CrossRef]

5. Seeberg, M.L. Immigrant careworkers and Norwegian gender equality: Institutions, identities, intersections. Eur. J. Women Stud. 2012, 19, 173-185. [CrossRef] 
6. Beyrer, S.; Hjemås, G.; Skjøstad, O.; Hansen, J. Helsefagarbeideres Arbeidssted og Nyutdannede Helsefagarbeideres Tilknytning til Arbeidslivet [Health professionals' workplace and recently qualified health professionals' affiliation to working life]; Statistisk Sentralbyrå: Oslo, Norway, 2019.

7. $\quad$ Eide Kjærgård, H.M.; Homme, A.; Karlsen, M.-A.; Lundberg, K. Integrering i praksis: Helse—og omsorgssektoren som opplæringsarena for flyktninger og innvandrere [Integration in Practice-and the Healthcare Sector as a Training Arena for Refugees and Immigrants]; Uni Research Rokkansenteret: Bergen, Norway, 2016.

8. Frøyland, K.; Spjelkavik, Ø. Inkluderingskompetanse [Inclusion Competence]; Gyldendal Akademisk: Oslo, Norway, 2014.

9. Statistics Norway. Innvandrere stod for en av 6 årsverk innen omsorg. [Immigrant Workers in One of Six Full-Time Equivalents in Long-Term Care]. 2018. Available online: https://www.ssb.no/helse/artikler-ogpublikasjoner/innvandrerne-sto-for-1-av-6-arsverk-innen-omsorg (accessed on 5 July 2018).

10. Christensen, K.; Hussein, S.; Ismail, M. Migrants' decision-process shaping work destination choice: The case of long-term care work in the United Kingdom and Norway. Eur. J. Aging 2016, 14, 219-232. [CrossRef]

11. Tjerbo, T.; Aamodt, P.O.; Stigen, I.M.; Helgesen, M.; Næss, T.; Arnesen, C.Å.; Høst, H.; Frølich, N. Bemanning av pleie- og omsorgsektoren: Handlingsplan og iverksetting [Staffing in the nursing and health care sector: Action plan and implementation]. NIBR Notat. 2012, 3.

12. Statistics Norway. Helse- og sosialpersonell [Health and Social Care Workers]. 2020. Available online: https://www.ssb.no/arbeid-og-lonn/statistikker/hesospers (accessed on 28 February 2020).

13. Howe, J.; Charlesworth, S.; Brennan, D. Migration pathways for frontline care workers in Australia and New Zealand: Front doors, side doors, back doors and trapdoors. UNSWLJ 2019, 42, 211. [CrossRef]

14. Fagertun, A. The anti-politics of healthcare policy and its blurring effects on care work in Norway. Int. Pract. Dev. J. 2017. [CrossRef]

15. Jesnes, K. Approaches to Atypical and Precarius Work; Fafo: Oslo, Norway, 2018.

16. Jacobsen, F.; Mekki, T. Health and the Changing Welfare State in Norway: A Focus on Municipal Health Care for Elderly Sick. Ageing Int. 2012, 37, 125-142. [CrossRef]

17. Fagertun, A.; Tingvold, L. Omsorgsarbeid, kjønn og etnisitet. Flerkulturelle arbeidsfelleskap i norske sykehjem i møte med institusjonelle endringer. (Care work, gender and ethnicity. Multicultural staffteams in Norwegian nursing homes). In Migrasjon, Helse og Profesjon; Debesay, J., Tschudi-Madsen, C., Eds.; Gyldendal: Oslo, Norway, 2018.

18. Orupabo, J.; Nadim, M. Men doing women's dirty work: Desegregation, immigrants and employer preferences in the cleaning industry in Norway. Gender Work Organ. 2019. [CrossRef]

19. Waerness, K.; Ringen, S. 7 Women in the Welfare State: The Case of Formal and Informal Old-Age Care. Int. J. Soc. 1986, 16, 161-173. [CrossRef]

20. Ramm, J. Eldres Bruk av Helse- og Omsorgstjenester. [The Elderly and Their Use of Long-Term Care Services]; Statistisk Sentralbyrå: Oslo, Norway, 2013.

21. Breman, J.; Linden, M. Informalizing the Economy: The Return of the Social Question at a Global Level. Dev. Chang. 2014, 45, 920-940. [CrossRef]

22. Fagertun, A. Absorbing care through precarious labor: The shifting boundaries of politics in Norwegian health care. In Intimacy and Mobility in the Era of Hardening Borders: Gender, Reproduction, Regulation; Haukanes, H., Pine, F.P., Eds.; Manchester University Press: Manchester, UK, 2020; forthcoming.

23. Friberg, J.H.; Midtbøen, A.H. The making of immigrant niches in an affluent welfare state. Int. Migr. Rev. 2019, 53, 322-345. [CrossRef]

24. Crenshaw, K. Mapping the margins: Intersectionality, identity politics, and violence against women of color. Stan. L Rev. 1990, 43, 1241. [CrossRef]

25. Cho, S.; Crenshaw, K.W.; McCall, L. Toward a field of intersectionality studies: Theory, applications, and praxis. Signs J. Women Cult. Soc. 2013, 38, 785-810. [CrossRef]

26. Mooney, S. 'Nimble'intersectionality in employment research: A way to resolve methodological dilemmas. Work Employ. Soc. 2016, 30, 708-718. [CrossRef]

27. Christensen, K.; Wærness, K. Long-term care services in Norway. A historical sociological perspective. In The Routledge Handbook of Social Care Work Around the World; Christensen, K., Pilling, D., Eds.; Routledge: Abingdon, UK, 2018; pp. 15-28.

28. Szebehely, M.; Meagher, G. Nordic eldercare-Weak universalism becoming weaker? J. Eur. Soc. Policy 2018, 28, 294-308. [CrossRef] 
29. Helvik, A.-S.; Engedal, K.; Selbæk, G. The quality of life and factors associated with it in the medically hospitalised elderly. Aging Ment. Health 2010, 14, 861-869. [CrossRef]

30. Isaksen, L.W. Transnational Spaces of Care: Migrant Nurses in Norway. Soc. Politics 2012, 19, 58-77. [CrossRef]

31. Atanackovic, J.; Bourgeault, I.L.; Rashid, A.; Parpia, R. Relations between Immigrant Care Workers and Older Persons in Home and Long-Term Care. Can. J. Aging 2010, 29, 109-118.

32. Boge, J. The inferior position of the Sámi language in a bilingual nursing home in Norway. J. Multiling. Multicult. Dev. 2019, 1-11. [CrossRef]

33. Kokkonen, A.; Esaiasson, P.; Gilljam, M. Diverse Workplaces and Interethnic Friendship Formation-A Multilevel Comparison across 21 OECD Countries. J. Ethn. Migr. Stud. 2015, 41, 284-305. [CrossRef]

34. Prasad, P.; Pringle, J.; Konrad, A. Examining the contours of workpalce diversity: Concepts, contexts and challenges. In Handbook of Workplace Diversity; Konrad, A., Prasad, P., Pringle, J., Eds.; Sage: London, UK, 2006; pp. 1-22.

35. Thuesen, F. Linguistic barriers and bridges: Constructing social capital in ethnically diverse low-skill workplaces. Work Employ. Soc. 2017, 31, 937-953. [CrossRef]

36. Yi, M.; Jezewski, M.A. Korean nurses' adjustment to hospitals in the United States of America. J. Adv. Nurs. 2000, 32, 721-729. [CrossRef]

37. Magnusdottir, H. Overcoming strangeness and communication barriers: A phenomenological study of becoming a foreign nurse. Int. Nurs. Rev. 2005, 52, 263-269. [CrossRef]

38. Chun Tie, Y.; Birks, M.; Mills, J. The experiences of internationally qualified registered nurses working in the Australian healthcare system: An integrative literature review. J. Transcult. Nurs. 2018, 29, 274-284. [CrossRef]

39. $\mathrm{Xu}, \mathrm{Y}$. Strangers in strange lands: A metasynthesis of lived experiences of immigrant Asian nurses working in Western countries. Adv. Nurs. Sci. 2007, 30, 246-265. [CrossRef]

40. Xu, Y.; Gutierrez, A.; Kim, S.H. Adaptation and transformation through (un) learning: Lived experiences of immigrant Chinese nurses in US healthcare environment. Adv. Nurs. Sci. 2008, 31, E33-E47. [CrossRef]

41. Näre, L. Migrancy, gender and social class in domestic labor and social care in Italy: An intersectional analysis of demand. J. Ethn. Migr. Stud. 2013, 39, 601-623. [CrossRef]

42. Priest, N.; Esmail, A.; Kline, R.; Rao, M.; Coghill, Y.; Williams, D.R. Promoting equality for ethnic minority NHS staff-What works? BMJ 2015, 351. [CrossRef]

43. Stevens, M.; Hussein, S.; Manthorpe, J. Experiences of racism and discrimination among migrant care workers in England: Findings from a mixed-methods research project. Ethn. Racial Stud. 2012, 35, 259-280. [CrossRef]

44. Omeri, A.; Atkins, K. Lived experiences of immigrant nurses in New South Wales, Australia: Searching for meaning. Int. J. Nurs. Stud. 2002, 39, 495-505. [CrossRef]

45. Eraut, M. Non-formal learning and tacit knowledge in professional work. Br. J. Educ. Psychol. 2010, 70, 113-136. [CrossRef]

46. Wacquant, L. For a Sociology of Flesh and Blood. Qual. Soc. 2015, 38, 1-11. [CrossRef]

47. McBride, A.; Hebson, G.; Holgate, J. Intersectionality: Are we taking enough notice in the field of work and employment relations? Work Employ. Soc. 2015, 29, 331-341. [CrossRef]

48. Sloan, L.; Joyner, M.; Stakeman, C.; Schmitz, C. Critical Multiculturalism and Intersectionality in a Complex World; Oxford University Press: Cambridge, UK, 2018.

49. Young, I.M. Justice and the Politics of Difference; Princeton University Press: Princeton, NJ, USA, 2011.

50. Dipboye, R.L.; Halverson, S.K. Subtle (and not so subtle) discrimination in organizations. Dark Side Organ. Behav. 2004, 16, 131-158.

51. Braun, V.; Clarke, V. Using thematic analysis in psychology. Qual. Res. Psychol. 2006, 3, 77-101. [CrossRef]

52. Van Laer, K.; Janssens, M. Ethnic minority professionals' experiences with subtle discrimination in the workplace. Human Relat. 2011, 64, 1203-1227. [CrossRef]

53. Munkejord, M.C. Ulik praksis for godkjenning av utdanning [Varying practices for approval of study programmes]. Sykepleien 2017, 105, 44-47. [CrossRef]

54. Van Riemsdijk, M. Variegated privileges of whiteness: Lived experiences of Polish nurses in Norway. Soc. Cult. Geogr. 2010, 11, 117-137. [CrossRef] 
55. Fagertun, A. Waves of dispossession: The conversion of land and labor in Bali's recent history. Soc. Anal. 2017, 61, 108-125. [CrossRef]

56. Behtoui, A.; Boréus, K.; Neergaard, A.; Yazdanpanah, S. Speaking up, leaving or keeping silent: Racialized employees in the Swedish elderly care sector. Work Employ. Soc. 2017, 31, 954-971. [CrossRef]

57. Kawi, J.; Xu, Y. Facilitators and barriers to adjustment of international nurses: An integrative review. Int. Nurs. Rev. 2009, 56, 174-183. [CrossRef] [PubMed]

58. Fossbråten, L.; Tingvold, L. Yrkesrettet Språkopplæring i Helsearbeiderfag [Vocational Language Training in Health Work Subjects]; Rapport, USHT: Førde, Norway, 2016.

59. Janssens, M.; Zanoni, P. Alternative diversity management: Organizational practices fostering ethnic equality at work. Scand. J. Manag. 2014, 30,317-331. [CrossRef]

(C) 2020 by the authors. Licensee MDPI, Basel, Switzerland. This article is an open access article distributed under the terms and conditions of the Creative Commons Attribution (CC BY) license (http://creativecommons.org/licenses/by/4.0/). 